\title{
EFFECTS OF MIXED FEEDING SCHEDULES ON GROWTH PERFORMANCE, BODY COMPOSITION, AND NITROGEN- AND PHOSPHORUS BALANCE IN RAINBOW TROUT, ONCORHYNCHUS MYKISS
}

\author{
Hüseyin SEVGILI ${ }^{1 *}$, Y1lmaz EMRE ${ }^{1}$, Mahir KANYILMAZ1, \\ İbrahim DILER ${ }^{1}$, Belgin HOŞSU ${ }^{2}$ \\ ${ }^{1}$ Directory of Mediterranean Fisheries Research Production and Training Institute, Kepez, Antalya, Turkey \\ ${ }^{2}$ Aegean University, Faculty of Fisheries, İzmir, Turkey
}

Sevgili H., Emre Y., Kanyilmaz M., Diler İ., Hoşsu B. 2006. Effects of mixed feeding schedules on growth performance, body composition, and nitrogen- and phosphorus balance in rainbow trout, Oncorhynchus mykiss. Acta Ichthyol. Piscat. 36 (1): 49-55.

Background. Reducing feed cost and the pollution originating from feed have been principal matters in fish nutrition. Mixed feeding schedules have been proposed as one of the methods to reduce both of them and successfully tested in many fish species. The aim of the present study was to determine the mixed feeding schedules' suitability for culture of rainbow trout.

Materials and Methods. Five different feeding schedules were tried by alternating the presentation of a low-protein $(28.1 \%) \operatorname{diet}(\mathrm{A})$ and a high-protein (49.9\%) diet (B). The feeding schedules employed were $1 \mathrm{~A} / 1 \mathrm{~B}, 1 \mathrm{~A} / 2 \mathrm{~B}, 1 \mathrm{~A} / 3 \mathrm{~B}$, $2 \mathrm{~A} / 2 \mathrm{~B}$, and $2 \mathrm{~A} / 3 \mathrm{~B}$ where the numerical values refer to the number of days each diet $(\mathrm{A}$ and $\mathrm{B}$ ) was offered continuously. Fish given diets A and B continuously served as controls. Totally, seven dietary treatments were tested in triplicate for 10 weeks.

Results. The fish maintained on the different mixed feeding schedules exhibited lower weight gain than those fed continuously on the high-protein $\operatorname{diet}(P<0.05)$. The fish reared on schedule $1 \mathrm{~A} / 3 \mathrm{~B}(1$ day diet $\mathrm{A}$ alternated with 3 days diet $\mathrm{B}$ ) had similar specific growth rate (SGR), feed conversation ratio (FCR), and protein efficiency ratio (PER) to those fed diet $\mathrm{B}$ continuously and was best among all mixed feeding schedules. However, the most cost-effective treatment was $2 \mathrm{~A} / 2 \mathrm{~B}$. In addition, this group compared to $\mathrm{B}$ resulted in significant increase and reduction of phosphorus retention and discharge, respectively $(P<0.05)$. The treatments significantly effected body moisture, fat- and ash levels $(P$ $<0.05$ ), but not protein.

Conclusion. The study shows that mixed feeding schedules are promising for use in rainbow trout culture as they result in feed cost saving and reduced phosphorus discharge in the effluents.

Keywords: mixed feeding schedules, growth, dietary protein, nitrogen and phosphorus balance, feed cost, rainbow trout, Oncorhynchus mykiss, fish

\section{INTRODUCTION}

From an economical viewpoint, feed cost is the highest of the operational costs in intensive aquaculture. It has been well established that in all fish diets, irrespective of the species, protein is the most important dietary nutrient and fishmeal remains one of the major source of dietary protein (Kaushik 1989). It is often suggested that fishmeal demand of aquaculture is likely to be a major issue for aquaculture development, particularly of carnivorous, high valued species, in the foreseeable future (Hardy 2000). In addition, fishmeal contains relatively high level of phosphorus $(\mathrm{P})$, which is critical in freshwaters (Sugiura and
Hardy 2000). Therefore, reducing fishmeal in fish diets is of importance in terms of feed costs and reduction of environmental effects from aquaculture operations.

The general approach adopted to reduce feed costs has been mainly on the substitution of fishmeal by cheaper protein sources (Tacon and Jackson 1985, Kaushik 1989). Based on the observation that the dry matter and protein digestibility varies from day to day in a certain rhythmic fashion in green chromide, Etroplus suratensis, (cf. De Silva and Perera 1983) and Nile tilapia, Oreochromis niloticus, (cf. De Silva and Perera 1984), De Silva (1985) postulated that the application of mixed feeding schedules

\footnotetext{
${ }^{*}$ Correspondence: Hüseyin Sevgili, Akdeniz Su Ürünleri Araştırma Üretim ve Eğitim Enstitüsü Müdürlüğü (Directory of Mediterranean Fisheries Research Production and Training Institute) 07001, PO Box: 190, Kepez, Antalya, Turkey, phone: +90-(242) 2510585, fax:+90-(242) 2510584, e-mail: husevgili@akdenizsuurunleri.gov.tr
} 
where a high-protein diet was alternated with a low-protein diet could result in improved nutrient utilization. The applicability of mixed feeding schedules in reducing feed costs and improving nutrient utilization has been demonstrated in Indian carps, Catla catla and Labeo rohita (cf. Nandeesha at al. 1993, 1994); common carp, Cyprinus carpio (cf. Srikanth et al. 1989; Nandeesha et al. 1995, 2002); Nile tilapia, Oreochromis niloticus (cf. Patel and Yakupitiyage 2003); sutchi catfish, Pangasius hypophthalmus; and silver carp, Hypophthalmichthys molitrix (cf. Ali et al. 2005).

There is strong evidence to indicate that nitrogen $(\mathrm{N})$ and phosphorus $(\mathrm{P})$, originating in aquaculture effluents, contribute significantly to eutrophication in the aquatic environment and the ultimate source of the pollution is feed (De Silva and Anderson 1995, Sugiura and Hardy 2000, Cho and Bureau 2001). Several options have been proposed to reduce the $\mathrm{N}$ and $\mathrm{P}$ discharges from aquaculture and include the use of well-balanced diets in terms of energy and protein and/or amino acids and diets with high digestibility (Cho and Bureau 2001), supplementation of phytase to the diets with high plant based-ingredients (Sugiura et al. 2000b, Vielma et al. 2002), reduction of fishmeal contents (Vielma et al. 1999, Sugiura et al. 2000a) and periodic feeding of fish with low and high $\mathrm{P}$ diets (Hardy et al. 1993). According to De Silva (1985) and De Silva and Anderson (1995) it is possible to reduce feed costs and pollution of aquaculture through employing mixed feeding schedules.

Therefore, the present study was planned to determine the effects of the use of mixed feeding schedules on growth, body composition and the retention, and losses of nitrogen and phosphorus in rainbow trout, a carnivorous species which is cultured intensively.

\section{MATERIALS AND METHODS}

This study was conducted at the Directory of Mediterranean Fisheries Research Production and Training Institute, Antalya, Turkey. The experiment was carried out over 70 days using rainbow trout with $35.0 \pm 0.1 \mathrm{~g}$ of average initial weight, in 21 rectangular fibreglass tanks of approximately $200-\mathrm{L}$ water capacity. Thirty fish were randomly allocated to each tank and acclimatized to experimental conditions by feeding the experimental high-protein diet for 2 weeks before commencement of the trial. Water was passed through a filter with $1 \mathrm{~mm}$ mesh size and flow rate was maintained at $10 \mathrm{~L} \cdot \mathrm{min}^{-1}$ throughout the study. Feed was offered at $2 \%$ of body weight per day, twice a day at 0900 and $1530 \mathrm{~h}$. Feed quantity was adjusted based on biweekly total batch weighing. Twenty fish were taken for initial carcass analysis during stocking whereas four fish at random from each tank were taken for final carcass analysis at the end of the experiment. Whole fish was minced through a meat mincer, immediately dried at $105^{\circ} \mathrm{C}$ overnight, placed in plastic bags, and frozen at $-20^{\circ} \mathrm{C}$ until analysis. Fish were maintained under natural photoperiod which ranged between 10/14 (light/dark) and 12/12 (light/dark) throughout the study. Water parameters such as temperature, dissolved oxygen, and $\mathrm{pH}$ were weekly monitored with YSI 58 DO Meter (Yellow Springs Instrument, Yellow Springs, OH, USA) and a $\mathrm{pH}$ meter (Expandable IonAnalyzer EA, Orion Research, Cambridge, MA, USA). Water temperature, dissolved oxygen, and $\mathrm{pH}$ values of the tanks were $14.47 \pm 0.76^{\circ} \mathrm{C}, 7.84 \pm$ $0.46 \mathrm{mg} \cdot \mathrm{L}^{-1}$, and $7.78 \pm 0.06$, respectively.

Seven dietary treatments were tested in triplicate tanks. In the trial, regular feeding with continuously either a lowprotein diet $(28.1 \%)$ or high-protein diet $(49.9 \%)$ served as controls. The five mixed feeding schedules were $1 \mathrm{~A} / 1 \mathrm{~B}$, $1 \mathrm{~A} / 2 \mathrm{~B}, 1 \mathrm{~A} / 3 \mathrm{~B}, 2 \mathrm{~A} / 2 \mathrm{~B}$, and $2 \mathrm{~A} / 3 \mathrm{~B}$, where the numerical value refers to the number of days that a particular diet is offered.

The ingredients and proximate composition of the diets are presented in Table 1. In the low-protein diet, fishmeal was totally replaced with full-fat soybean and blood meal and fish oil was not incorporated. The diets were not prepared to be isoenergetic. Ingredients used were purchased from the local market, weighed at predetermined levels, and mixed through an experimental type horizontal mixer for five min. Then, the diets were pelleted using a pelleting machine (4-mm pellet diameter) without steam and packed in plastic bags until used. Feed conversion ratio (FCR), average weight gain (AWG), specific growth rate (SGR), protein efficiency ratio (PER), condition factor (CF), hepatosomatic index (HSI), and dress-out percentage (DOP) were calculated according to Metailler (1987) and Goddard (1996), and the retention and losses of $\mathrm{N}$ and $\mathrm{P}$ according to Paspatis et al. (2000) and Vielma et al. (2002). Feed costs per unit AWG were calculated by multiplying diet prices in New Turkish Lira (YTL $\cdot \mathrm{kg}^{-1}$ ) of each treatment with their respective average FCR values. In the estimation of cost saving of the schedules, feed cost of treatment B was assumed as $100 \%$.

Ingredients, experimental diets, and fish samples were analysed for proximate composition and $\mathrm{P}$ contents according to AOAC (Anonymous 1990). Gross energy was calculated using conversion factors of $39.5,23.7$, and 17.2 $\mathrm{MJ} \cdot \mathrm{kg}^{-1}$ for fat, protein, and carbohydrate, respectively (Young et al. 2005). One-way analysis of variance (ANOVA) was employed to reveal the effects of treatments on the criteria selected and then Duncan's multiple range test was performed (Duncan 1955). All percentage values were arcsine transformed before analysis of variance. A significance level of $P<0.05$ was used.

\section{RESULTS}

The initial and final mean weights and growth parameters: AWG, SGR, FCR, and PER; body indices: CF, HIS, and DOP; and feed cost analysis are presented in Table 2. Fish fed high-protein diet (B) continuously performed significantly better than the others $(P<0.05)$ whereas those on the low-protein $\operatorname{diet}(\mathrm{A})$ continuously showed the poorest growth (Fig. 1). The SGR of fish fed continuously a high-protein diet was significantly higher $(P<0.05)$ than the other treatments, except for those fish on the mixed schedule $1 \mathrm{~A} / 3 \mathrm{~B}$. The FCR also followed the same trend 
Table 1

Ingredient and proximate composition of experimental diets

\begin{tabular}{|c|c|c|}
\hline \multicolumn{3}{|c|}{ Diets } \\
\hline Ingredient $[\%]$ & A & $\mathrm{B}$ \\
\hline Fish meal & - & 59.3 \\
\hline Full-fat soy bean & 45.0 & - \\
\hline Blood meal & 7.4 & - \\
\hline Wheat & 37.0 & - \\
\hline Wheat middling & 9.2 & 27.6 \\
\hline Fish oil & - & 11.7 \\
\hline Vitamin 1 & 0.5 & 0.5 \\
\hline Mineral $^{2}$ & 0.2 & 0.2 \\
\hline Lignosulfonate & 0.3 & 0.3 \\
\hline Choline chloride & 0.15 & 0.15 \\
\hline Antioxidant $^{3}$ & 0.25 & 0.25 \\
\hline \multicolumn{3}{|c|}{ Proximate composition [\% dry matter basis] } \\
\hline Dry matter & 89.7 & 91.0 \\
\hline Protein & 28.1 & 49.9 \\
\hline Crude fat & 12.2 & 19.9 \\
\hline Ash & 4.8 & 8.9 \\
\hline $\mathrm{P}$ & 0.5 & 1.7 \\
\hline Gross energy [MJ kg-1] & 19.2 & 21.8 \\
\hline Price $\left[\mathrm{YTL} \cdot \mathrm{kg}^{-1}\right]$ & 0.558 & 1.157 \\
\hline
\end{tabular}

${ }^{1}$ Per 1 kg of premix: 4000000 IU vitamin A, 480000 IU vitamin $D_{3}, 40000 \mathrm{mg}$ vita$\min$ E, $2400 \mathrm{mg}$ vitamin $\mathrm{K}_{3}, 4000 \mathrm{mg}$ vitamin $\mathrm{B}_{1}, 6000 \mathrm{mg}$ vitamin $\mathrm{B}_{2}, 40000 \mathrm{mg}$ niacin, $10000 \mathrm{mg}$ Ca-pantothenate, $4000 \mathrm{mg}$ vitamin $\mathrm{B}_{6}, 10 \mathrm{mg}$ vitamin $\mathrm{B}_{12}, 100 \mathrm{mg}$ D-biotin, $1200 \mathrm{mg}$ folic acid, $40000 \mathrm{mg}$ vitamin $\mathrm{C}$ and $60000 \mathrm{mg}$ inositol;

2 Per 1 kg of premix: 23750 mg Mn, 75000 mg Zn, 5000 mg Zn, 2000 mg Co, 2750 mg I, $100 \mathrm{mg} \mathrm{Se}, 200000 \mathrm{mg} \mathrm{Mg}$;

${ }^{3}$ Butylated hydroxytoluene; YTL, New Turkish Lira

among the treatments. Fish fed continuously the low-protein diet had significantly lower PER $(P<0.05)$ than the other groups except for $2 \mathrm{~A} / 3 \mathrm{~B}$. The $\mathrm{CF}$ for $1 \mathrm{~A} / 1 \mathrm{~B}, 1 \mathrm{~A} /$ $2 \mathrm{~B}$, and $1 \mathrm{~A} / 3 \mathrm{~B}$ schedules were comparable to that of the high-protein control diet $(P>0.05)$. There were significant differences in HSI among the groups maintained on various mixed feeding schedules, the highest value being recorded in the group of fish maintained on $1 \mathrm{~A} / 3 \mathrm{~B}$ while the lowest was for A. However, DOP did not change in relation to the dietary treatment. The most economical feed cost per unit AWG was obtained in the group of fish reared on $2 \mathrm{~A} / 2 \mathrm{~B}$ schedule even though it yielded significantly reduced growth rate compared with the control receiving the highprotein diet continuously $(P<0.05)$.

Briefly, although group B showed the highest growth, fish maintained on $1 \mathrm{~A} / 3 \mathrm{~B}$, and $2 \mathrm{~A} / 2 \mathrm{~B}$ treatments had comparable performance to those on $\mathrm{B}$ but the former treatments resulted in the most feed cost saving.

Proximate composition of fish maintained on different mixed feeding schedules is given in Table 3 . The analysis of initial and final body compositions indicated a decline in moisture and ash and an increase in fat in all the dietary treatments. Treatments $\mathrm{A}$ and $2 \mathrm{~A} / 2 \mathrm{~B}$ reduced body moisture levels compared to $\mathrm{B}(P<0.05)$, which was not different from the others $(P>0.05)$. However, the final body protein was not affected by mixed feeding schedules. Feeding continuously diet A significantly lowered fat content over high-protein, B. A significant difference was observed in the ash level between the treatments $\mathrm{B}$ and 1A/1B $(P<0.05)$.

As seen in Table 4, fish maintained on A retained significantly more $\mathrm{P}$ than the other treatments which were not different among themselves except for $2 \mathrm{~A} / 2 \mathrm{~B}$ which had significantly better $\mathrm{P}$ retention than $\mathrm{B}(P<0.05)$. N retention and losses of the treatments were significantly lower and higher, respectively, for $\mathrm{A}$ than $\mathrm{B}(P<0.05)$. The best values concerning $\mathrm{N}$ retention and losses were observed in treatments $2 \mathrm{~A} / 2 \mathrm{~B}$ and $1 \mathrm{~A} / 3 \mathrm{~B}$ although not significantly different from $\mathrm{B}$.

\section{DISCUSSION}

Five mixed feeding schedules tested were randomly determined in the current study as by De Silva (1985) due to the fact that in our preliminary study, a well-defined va- 


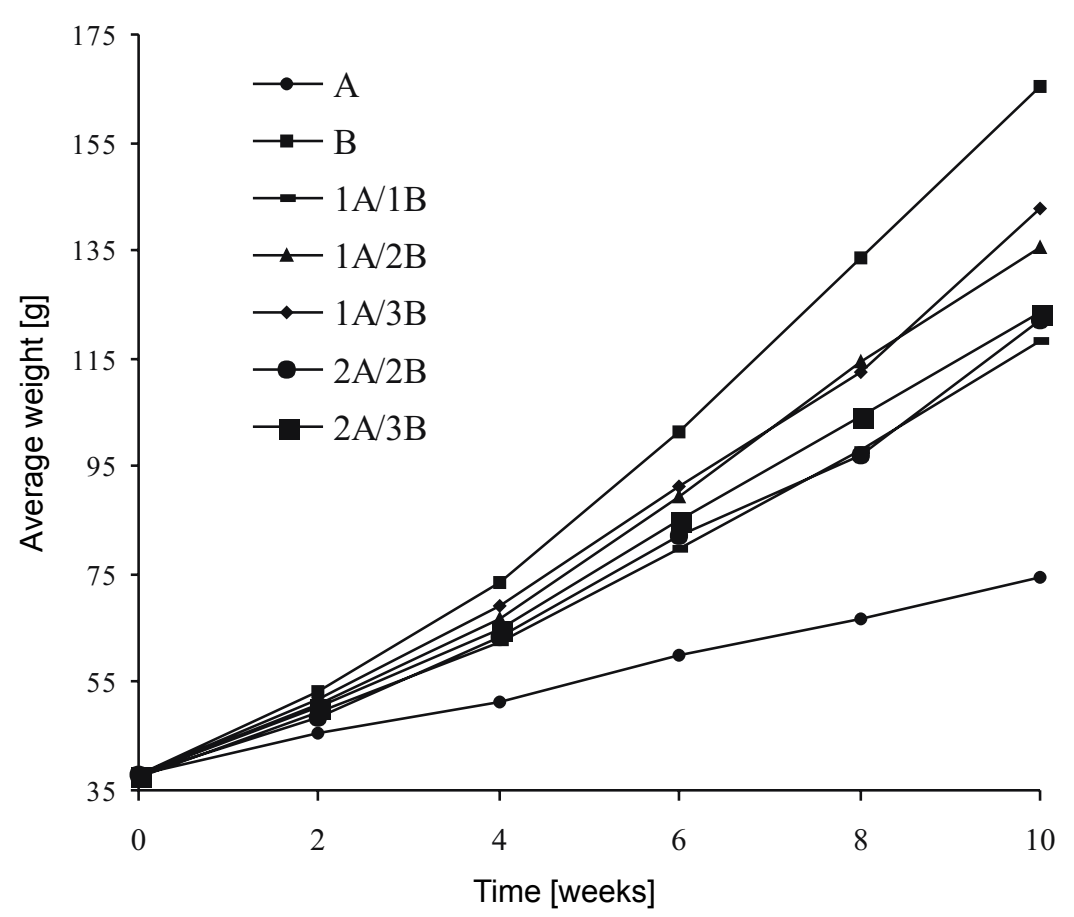

Fig. 1. Growth of rainbow trout fed on diets A, B, and mixed feeding schedules

riation pattern was not observed in dry matter and protein digestibility over 21 days (data not provided).

Even though protein requirement of rainbow trout has been reported to be $38 \%$ based on purified diets having relatively high-protein digestibility (Anonymous 1993), practical trout feeds are formulated to include $42 \%-48 \%$ pro- tein (Hardy 2002). In the current study, fish fed a highprotein diet continuously grew significantly better than those maintained on various mixed feeding schedules. Full fat soybean meal used instead of fishmeal in this study has been reported to lead to reduced growth when used in excess of $15 \%$ in salmonid diets (Hardy 1996, Li et al.

Table 2

Growth performance and feed utilization parameters, body indices, and feed cost analysis $(\bar{x} \pm s ; n=3)$ of rainbow trout maintained on different mixed feeding schedules

\begin{tabular}{|c|c|c|c|c|c|c|c|}
\hline \multicolumn{8}{|c|}{ Treatment* } \\
\hline Parameter & A & B & $1 \mathrm{~A} / 1 \mathrm{~B}$ & $1 \mathrm{~A} / 2 \mathrm{~B}$ & $1 \mathrm{~A} / 3 \mathrm{~B}$ & $2 \mathrm{~A} / 2 \mathrm{~B}$ & $2 \mathrm{~A} / 3 \mathrm{~B}$ \\
\hline Initial weight $[\mathrm{g}]$ & $37.8 \pm 0.1$ & $37.7 \pm 0.1$ & $37.6 \pm 0.0$ & $37.8 \pm 0.1$ & $37.8 \pm 0.1$ & $37.7 \pm 0.1$ & $37.7 \pm 0.1$ \\
\hline Final weight $[\mathrm{g}]$ & $74.6 \pm 0.8^{\mathrm{d}}$ & $165.4 \pm 12.2^{\mathrm{a}}$ & $118.4 \pm 3.4^{\mathrm{c}}$ & $135.5 \pm 6.8^{b c}$ & $142.6 \pm 5.1^{\mathrm{b}}$ & $122.3 \pm 6.3^{b c}$ & $123.8 \pm 5.1^{b c}$ \\
\hline AWG $\left[\mathrm{g} \cdot\right.$ fish $\left.^{-1}\right]$ & $36.8 \pm 0.7^{d}$ & $127.7 \pm 12.3^{\mathrm{a}}$ & $80.7 \pm 3.4^{c}$ & $97.8 \pm 6.9^{b c}$ & $104.8 \pm 5.1^{b}$ & $84.6 \pm 6.3^{b c}$ & $86.0 \pm 5.0^{\mathrm{bc}}$ \\
\hline SGR $[\%]$ & $1.0 \pm 0.0^{\mathrm{d}}$ & $2.1 \pm 0.1^{\mathrm{a}}$ & $1.6 \pm 0.0^{\mathrm{c}}$ & $1.8 \pm 0.1^{b c}$ & $1.9 \pm 0.1^{\mathrm{ab}}$ & $1.7 \pm 0.1^{\mathrm{c}}$ & $1.7 \pm 0.1^{b c}$ \\
\hline FCR & $2.0 \pm 0.0^{\mathrm{a}}$ & $0.9 \pm 0.1^{\mathrm{e}}$ & $1.2 \pm 0.1^{b}$ & $1.1 \pm 0.1 \mathrm{cde}$ & $1.0 \pm 0.0^{\mathrm{ed}}$ & $1.1 \pm 0.1^{\mathrm{bcd}}$ & $1.2 \pm 0.0^{\mathrm{bc}}$ \\
\hline PER [\%] & $1.8 \pm 0.0^{\mathrm{b}}$ & $2.2 \pm 0.1^{\mathrm{a}}$ & $2.1 \pm 0.1^{\mathrm{a}}$ & $2.2 \pm 0.1^{\mathrm{a}}$ & $2.3 \pm 0.1^{\mathrm{a}}$ & $2.3 \pm 0.1^{\mathrm{a}}$ & $2.1 \pm 0.1^{\mathrm{ab}}$ \\
\hline $\mathrm{CF}[\%]$ & $1.1 \pm 0.0^{\mathrm{d}}$ & $1.4 \pm 0.0^{\mathrm{a}}$ & $1.3 \pm 0.0^{\mathrm{ab}}$ & $1.3 \pm 0.0^{\mathrm{a}}$ & $1.3 \pm 0.0^{\mathrm{ab}}$ & $1.2 \pm 0.0^{\mathrm{bc}}$ & $1.2 \pm 0.0^{\mathrm{c}}$ \\
\hline HSI [\%] & $1.2 \pm 0.0^{\mathrm{e}}$ & $1.4 \pm 0.1^{\mathrm{bcd}}$ & $1.4 \pm 0.0^{\mathrm{cd}}$ & $1.5 \pm 0.0^{\mathrm{abc}}$ & $1.6 \pm 0.0^{\mathrm{a}}$ & $1.5 \pm 0.0^{\mathrm{ab}}$ & $1.4 \pm 0.1^{\mathrm{d}}$ \\
\hline DOP $[\%]$ & $86.3 \pm 0.1$ & $86.3 \pm 0.8$ & $86.1 \pm 0.9$ & $86.8 \pm 2.3$ & $86.9 \pm 0.7$ & $87.3 \pm 0.2$ & $88.4 \pm 0.2$ \\
\hline $\mathrm{FC}$ & 1.101 & 1.087 & 1.056 & 1.012 & 1.003 & 0.967 & 1.051 \\
\hline \multicolumn{8}{|l|}{$\left[\mathrm{YTL} \cdot \mathrm{kg} \mathrm{AWG}^{-1}\right]$} \\
\hline Cost saving [\% ] & -1.3 & - & 2.8 & 6.9 & 7.71 & 1.0 & 3.3 \\
\hline
\end{tabular}

Figures in the same row with different superscripts are significantly different $(P<0.05)$; ${ }^{*}(\mathrm{~A})$ is low-protein $\operatorname{diet}(28.1 \%$ protein diet), (B) is high-protein diet (49.9\% protein diet), numerals indicate the number of days during which any particular diet is offered continuously; $\mathrm{AWG}=$ Final weight [g]-Initial weight $[\mathrm{g}], \mathrm{SGR}=100\left[\ln \mathrm{Wf}-\ln \mathrm{W}_{\mathrm{i}}\right] /$ time (days) where $\mathrm{W}_{\mathrm{f}}$ is final weight, $\mathrm{W}_{\mathrm{i}}$ is initial weight, $\mathrm{FCR}=$ Total feed $[\mathrm{g}] /$ Total weight gain $[\mathrm{g}], \mathrm{PER}=$ Wet weight gain $[\mathrm{g}] /$ Protein fed $[\mathrm{g}], \mathrm{CF}=$ Final weight $[\mathrm{g}] /$ Fork length $[\mathrm{cm}] \times 100$, HSI $=$ Liver weight $[\mathrm{g}] /$ Whole weight $[\mathrm{g}] \times 100, \mathrm{DOP}=$ Viscera $[\mathrm{g}] /$ Whole weight $[\mathrm{g}] \times 100, \mathrm{YTL} ; \mathrm{New}$ Turkish Lira, FC $($ Feed Cost $)=$ Price $\left[\mathrm{YTL} \cdot \mathrm{kg}^{-1}\right] \times \mathrm{FCR}$ 
Table 3

Initial and final body composition $(\bar{x} \pm s ; n=3)$ of rainbow trout maintained on mixed feeding schedules

\begin{tabular}{|c|c|c|c|c|c|c|c|c|}
\hline \multicolumn{9}{|c|}{ Treatment ${ }^{*}$} \\
\hline & Initial & A & B & $1 \mathrm{~A} / 1 \mathrm{~B}$ & $1 \mathrm{~A} / 2 \mathrm{~B}$ & $1 \mathrm{~A} / 3 \mathrm{~B}$ & $2 \mathrm{~A} / 2 \mathrm{~B}$ & $2 \mathrm{~A} / 3 \mathrm{~B}$ \\
\hline Moisture [\%] & 74.0 & $71.9 \pm 0.2^{\mathrm{a}}$ & $69.1 \pm 0.7^{c}$ & $70.6 \pm 0.8^{a b c}$ & $70.2 \pm 0.6^{\mathrm{abc}}$ & $69.4 \pm 0.6^{b c}$ & $71.0 \pm 0.6^{\mathrm{ab}}$ & $69.8 \pm 0.6^{b c}$ \\
\hline Protein $[\%]$ & 16.1 & $15.4 \pm 0.5$ & $16.4 \pm 0.4$ & $15.2 \pm 0.7$ & $16.3 \pm 0.5$ & $16.4 \pm 0.1$ & $16.4 \pm 0.1$ & $16.0 \pm 0.2$ \\
\hline Fat $[\%]$ & 6.3 & $9.5 \pm 0.3^{b}$ & $11.6 \pm 0.5^{a}$ & $11.6 \pm 0.6^{\mathrm{a}}$ & $11.4 \pm 0.2^{\mathrm{a}}$ & $11.2 \pm 0.7^{\mathrm{a}}$ & $10.3 \pm 0.5^{\mathrm{a}}$ & $11.0 \pm 0.1^{\mathrm{a}}$ \\
\hline Ash $[\%]$ & 2.6 & $2.2 \pm 0.3^{\mathrm{ab}}$ & $2.3 \pm 0.5^{\mathrm{a}}$ & $2.1 \pm 0.0^{\mathrm{ab}}$ & $2.0 \pm 0.1^{b}$ & $2.1 \pm 0.02^{\mathrm{ab}}$ & $2.1 \pm 0.0^{\mathrm{ab}}$ & $2.2 \pm 0.1 \mathrm{a}^{\mathrm{b}^{*}}$ \\
\hline
\end{tabular}

See footnote of Table 2; figures in the same row with different superscripts are significantly different $(P<0.05)$

Table 4

$\mathrm{P}$ and $\mathrm{N}$ retention and losses $(\bar{x} \pm s ; n=3)$ of fish reared on mixed feeding schedules

Treatment*

\begin{tabular}{|c|c|c|c|c|c|c|c|}
\hline Parameter & A & B & $1 \mathrm{~A} / 1 \mathrm{~B}$ & $1 \mathrm{~A} / 2 \mathrm{~B}$ & $1 \mathrm{~A} / 3 \mathrm{~B}$ & $2 \mathrm{~A} / 2 \mathrm{~B}$ & $2 \mathrm{~A} / 3 \mathrm{~B}$ \\
\hline P retention [\%] & $79.2 \pm 2.1^{\mathrm{a}}$ & $39.7 \pm 4.6^{\mathrm{c}}$ & $45.6 \pm 1.1^{b c}$ & $46.3 \pm 3.2^{b c}$ & $43.8 \pm 3.4 b^{c}$ & $53.1 \pm 1.7^{\mathrm{b}}$ & $47.0 \pm 3.3^{b c}$ \\
\hline $\mathrm{P}$ loss $\left[\mathrm{g} \cdot \mathrm{kg}^{-1}\right]$ & $2.1 \pm 0.2^{\mathrm{c}}$ & $9.8 \pm 1.3^{\mathrm{a}}$ & $7.4 \pm 0.6^{\mathrm{ab}}$ & $7.4 \pm 0.7^{\mathrm{ab}}$ & $7.9 \pm 0.7^{\mathrm{ab}}$ & $5.9 \pm 0.4^{b}$ & $8.0 \pm 0.8^{\mathrm{ab}}$ \\
\hline $\mathrm{N}$ retention [\%] & $26.3 \pm 1.5^{\mathrm{c}}$ & $35.3 \pm 2.7^{\mathrm{ab}}$ & $30.9 \pm 1.0^{b c}$ & $36.5 \pm 3.2^{\mathrm{ab}}$ & $37.4 \pm 1.1^{\mathrm{a}}$ & $37.6 \pm 1.5^{\mathrm{a}}$ & $32.6 \pm 1.7^{\mathrm{ab}}$ \\
\hline $\mathrm{N}$ loss $\left[\mathrm{g} \cdot \mathrm{kg}^{-1}\right]$ & $65.3 \pm 0.8^{\mathrm{a}}$ & $48.7 \pm 4.7^{b}$ & $53.1 \pm 2.9^{b}$ & $46.0 \pm 4.3^{b}$ & $44.3 \pm 1.8^{\mathrm{b}}$ & $44.0 \pm 2.9^{b}$ & $52.8 \pm 3.2^{\mathrm{b}}$ \\
\hline
\end{tabular}

${ }^{*}$ See footnote of Table 2; figures in the same row with different superscripts are significantly different $(P<0.05)$; Nutrient retention $[\%]=($ nutrient deposited $[\mathrm{g}] /$ nutrient fed $[\mathrm{g}]) \times 100$; nutrient loss $\left[\mathrm{g} \cdot \mathrm{kg}^{-1}\right]=($ nutrient fed $[\mathrm{g}]-$ nutrient deposited $[\mathrm{g}]) /$ weight gain $[\mathrm{kg}]$

2000). The reason of low growth of fish reared on diet containing full-fat soybean compared with the fish meal based diet may be an insufficient amount of dietary protein, low-nutrient digestibility, high carbohydrate that can not be utilized by salmonids and anti nutritional factors of soybean (Kaushik 1989, Murai 1992, Refstie et al. 1998, Francis et al. 2001).

Of all mixed feeding schedules tested, the best growth performance was observed in fish on $1 \mathrm{~A} / 3 \mathrm{~B}$ schedule and these had similar SGR and FCR to those maintained on the high-protein diet continuously. Similarly, common carp maintained on the $1 \mathrm{~A} / 3 \mathrm{~B}$ schedule was found to grow well (Srikanth et al. 1989). Nandeesha et al. (1994) fed Indian major carps with rice bran (low-protein diet) and a mixture of rice-bran-groundnut meal cake (high-protein diet) using mixed feeding schedules and found that fish reared on the $1 \mathrm{~A} / 3 \mathrm{~B}$ schedule performed comparable growth with those fed continuously high-protein diet. Thus, it can be considered that this schedule is promising for rainbow trout as well.

The present results are in agreement with the data of Patel and Yakupitiyage (2003) in that mixed feeding schedules did not affect whole body protein in Nile tilapia. In the presently reported study, feeding continuously low-protein diet, however, resulted in significantly higher moister and lower fat levels than feeding continuously high-protein diet. A similar finding was also reported with common carp (Nandeesha et al. 1993, 2002, Srikanth et al.
1989) and sutchi catfish (Ali et al. 2005). This might be a result of the lower energy content of diet A or higher energy content of diet B as reported by Nandeesha et al. (2002).

The ultimate source of nitrogen, excreted by fish, is protein in the diet. Reducing the level of dietary protein to the minimum required level for fish is critical in commercial aquaculture, since excess portion of dietary protein is not only wasted as ammonia via gills, as far as fish growth is concerned, but it is also environmentally destructive (Sugiura and Hardy 2000). It was reported that mixed feeding schedules using diets containing low- and high-protein as in the present study provided an increased and decreased $\mathrm{N}$ retention and loss, respectively, in tilapia and carps (De Silva 1985, Nandeesha et al. 1993, 1994, 1995, Ali et al. 2005). In the presently reported study, the schedules used $(1 \mathrm{~A} / 1 \mathrm{~B}, 1 \mathrm{~A} / 2 \mathrm{~B}$ and $1 \mathrm{~A} / 3 \mathrm{~B})$ were in conformity with the above findings to a certain degree but these were not significantly different from the high-protein control diet. As mentioned above, the negative nutritional factors of the low-protein diet probably had a role on these values.

It is well known that as the levels of $\mathrm{P}$, calcium $(\mathrm{Ca})$, ash, bone and size of the bone particles, and phytic acid of fish feeds increase, the retention of $\mathrm{P}$ decreases (Riche and Brown 1996, 1999, Sugiura and Hardy 2000, Rodehutscord et al. 2000, Cho and Bureau 2001). Riche and Brown (1999) found that a significant increase in P retention of rainbow trout was observed when fishmeal was re- 
placed with plant protein sources. Satoh et al. (2003) compared a commercial feed and a diet containing plant protein source such as soybean meal, corn gluten etc., as protein sources in terms of availability of $\mathrm{P}$ in rainbow trout and found the later was superior to the commercial diet. Although P availability of plant feedstuffs is often limited to fish (Riche and Brown 1996, Sugiura and Hardy 2000, Cho and Bureau 2001, Francis et al. 2001), these researchers attributed the superior results of the plant-based diets to their lower $\mathrm{Ca}$ and $\mathrm{P}$ contents. Similarly, in the present study it was observed significantly better $\mathrm{P}$ retention and lower P losses in A and 2A/2B (the other schedules were also numerically better) compared with $\mathrm{B}$, which resulted from the use of plant feedstuffs in the low-protein diet. Therefore, it is concluded that mixed feeding schedules may be an efficient way to reduce $\mathrm{P}$ discharge from aquaculture effluent. On the other hand, there is a need the further investigations.

In aquaculture, the ultimate aim is not to achieve the highest mean weight (De Silva et al. 1989) but especially, in the current context practices, the emphasis is also on a low environmentally burden and the cost effectiveness. Consequently, although mixed feeding schedules tested failed to reach the growth of trout fed constantly high-protein, they provided the reduced feed cost and improved results in $\mathrm{P}$ balances. When these criteria are considered, the results from $1 \mathrm{~A} / 3 \mathrm{~B}$ and $2 \mathrm{~A} / 2 \mathrm{~B}$ schedules can be regarded as promising. The results obtained, suggested that the mixed feeding schedules merit further investigation as a way of reducing feed cost and the pollution originating from the diets of intensively cultured carnivorous species.

\section{ACKNOWLEDGEMENTS}

The General Directory of Agricultural Research, Ministry of Agriculture and Rural Affairs funded this study, under grant no. TAGEM HAYSÜD/2001/07/01/03. We would like to thank all of the staff working our institute for their help during the trial. We are grateful to S.S. De Silva and two anonymous referees for their valuable comments to improve the manuscript. The Directory of West Mediterranean Agriculture Research is also acknowledged for the analysis of protein.

\section{REFERENCES}

Ali M.Z., Hossain M.A., Mazid M.A. 2005. Effect of mixed feeding schedules with varying dietary protein levels on the growth of sutchi catfish, Pangasius hypophthalmus (Sauvage) with silver carp, Hypophthalmichthys molitrix (Valenciennes) in ponds. Aquaculture Research 36: 627-634.

Anonymous 1990. Official methods of analysis of AOAC International. 15th edn. Arlington, VA, USA.

Anonymous 1993. Nutrient requirements of fish. Subcommittee on Fish Nutrition, National Research Council. The National Academies Press, Washington, DC, USA.

Cho C.Y., Bureau D.P. 2001. A review of diet formulation strategies and feeding systems to reduce excretory and feed wastes in aquaculture. Aquaculture Research 32: 349-360.

Duncan D.B. 1955. Multiple-range and multiple F tests. Biometrics 11: $1-42$.
Francis G., Makkar H.P.S., Becker K. 2001. Antinutritional factors present in plant-derived alternate fish feed ingredients and their effects in fish. Aquaculture 199:197-227.

Goddard S. 1996. Feed management in intensive aquaculture. Chapman and Hall, New York.

Hardy R.W. 1996. Alternate protein sources for salmon and trout diets. Animal Feed Science and Technology 59: 71-80.

Hardy R.W. 2000. New developments in aquatic feed ingredients, and potential of enzyme supplements. Pp. 216-226. In: Cruz-Suárez L.E, Ricque-Marie D., Tapia-Salazar M., O1vera-Novoa M.A., Civera-Cerecedo R. (eds.) Avances en nutrición acuícola. V. Simposium Internacional de Nutrición Acuícola, 19-22 Noviembre 2000. Mérida, Yucatán, Mexico.

Hardy R.W. 2002. Rainbow trout, Oncorhynchus mykiss. Pp. 184-2002. In: Webster C.D., Lim C. (eds.) Nutrient requirements and feeding of finfish for aquaculture. CABI Publishing, Oxon, UK.

Hardy R.W., Fairgrieve W.T., Scott T.M. 1993. Periodic feeding of low-phosphorus diet and phosphorus retention in rainbow trout (Oncorhynchus mykiss). Pp. 403-412. In: Kaushik S.J., Luquet P. (eds.) Fish nutrition in practice. INRA Editions, Paris, France.

Kaushik S.J. 1989. Use of alternate protein sources for intensive rearing of carnivorous fishes. Pp. 191-201. In: Shiau S.Y. (ed.) Progress in fish nutrition. Marine Food Science Series, No. 9, Keeking, ROC, Taiwan.

Li M.H., Robinson E.H., Hardy R.W. 2000. Protein sources for feeds. Pp. 688-695. In: Stickney R.R. (ed.) Encyclopedia of aquaculture. John Wiley and Sons, New York.

Metailler R. 1987. Experimentation in nutrition. Pp. 303-330. In: Bruno A. (ed.) Nutrition in marine aquaculture. Rome, Italy.

Murai T. 1992. Protein nutrition of rainbow trout. Aquaculture 100: 191-207.

Nandeesha M.C., Gangadhara B., Manissery J.K. 2002. Further studies on the use of mixed feeding schedules with plant- and animal based diets for common carp Cyprinus carpio (Linnaeus). Aquaculture Research 33: 1157-1162.

Nandeesha M.C., Silva S.S. De, Krishna M.D. 1993. Evaluation of mixed feeding schedules in two Indian major carps, catla (Catla catla) and rohu (Labeo rohita). Pp. 753-765. In: Kaushik S.J., Luquet P. (eds.) Fish nutrition in practice. INRA Editions, Paris, France.

Nandeesha M.C., Silva S.S. De, Krishna M.D. 1995. Use of mixed feeding schedules in fish culture: performance of common carp, Cyprinus carpio L., on plant and animal based diets. Aquaculture Research 26: 161-166.

Nandeesha M.C., Silva S.S. De, Krishna M.D., Dathatri K. 1994. Use of mixed feeding schedules in fish culture. I. Field trials on catla, Catla catla (Hamilton-Buchanan) rohu, Labeo rohita (Hamilton) and common carp, Cyprinus carpio L. Aquaculture and Fisheries Management 25: 659-670.

Paspatis M., Boujard T., Maragoudaki D., Kentouri M. 2000. European sea bass growth and $\mathrm{N}$ and $\mathrm{P}$ loss under different feeding practices. Aquaculture 184: 77-88.

Patel A.B., Yakupitiyage A. 2003. Mixed feeding schedules in semi-intensive pond culture of Nile tilapia, Oreochromis ni- 
loticus, L.: Is it necessary to have two diets of differing protein contents? Aquaculture Research 34: 1343-1352.

Refstie S., Storebakken T., Roem A.J. 1998. Feed consumption and conversion in Atlantic salmon (Salmo salar) fed diets with fish meal, extracted soybean meal or soybean meal with reduced content of oligosaccharides, trypsin inhibitors, lectins and soya antigens. Aquaculture 162: 301-312.

Riche M., Brown P.B. 1996. Availability of phosphorus from feedstuffs fed to rainbow trout, Oncorhynchus mykiss. Aquaculture 142: 269-282.

Riche M., Brown P.B. 1999. Incorporation of plant protein feedstuffs into fish meal diets for rainbow trout increases phosphorus availability. Aquaculture Nutrition 5: 101-105.

Rodehutscord M., Gregus Z., Pfeffer E. 2000. Effect of phosphorus on faecal and non-faecal phosphorus excretion in rainbow trout (Oncorhynchus mykiss) and the consequences for comparative phosphorus availability studies. Aquaculture 188: 383-398.

Satoh S., Hernández A., Tokoro T., Morshita Y., Kiron V., Watanabe T. 2003. Comparison of phosphorus retention efficiency between rainbow trout (Oncorhynchus mykiss) fed a commercial diet and a low fish meal based diet. Aquaculture 224: 271-282.

Silva S.S. De, 1985. Performance of Oreochromis niloticus (L.) fry maintained on mixed feeding schedules of differing protein content. Aquaculture and Fisheries Management 16: 331-340.

Silva S.S. De, Anderson T.A. 1995. Fish nutrition in aquaculture. Chapman and Hall, London.

Silva S.S. De, Gunasekara R.M., Atapattu D. 1989. The dietary protein requirements of young tilapia and evaluation of the least cost dietary protein levels. Aquaculture 80: 271284.

Silva S.S. De, Perera M.K. 1983. Digestibility of an aquatic macrophyte by the cichlid Etroplus suratensis (Bloch) with observations on the relative merits of three indigenous components as markers and daily changes in protein digestibility. Journal of Fish Biology 23: 675-684.

Silva S.S. De, Perera M.K. 1984. Digestibility in Sarotheodon niloticus fry: Effects of protein level and salinity with further observations on variability in daily digestibility. Aquaculture 38: 293-306.
Srikanth G.K., Nandeesha M.C., Keshavanath P., Varghese T.J., Shetty H.P.C., Basavaraj N. 1989. On the applicability of mixed feeding schedule for common carp, Cyprinus carpio var. communis. Pp. 254-261. In: Huisman E.A., Zonneveld N., Boumans A.HM. (eds.) Aquaculture in Asia. Pudoc, Wageningen, The Netherlands.

Sugiura S.H., Babbitt J.K., Dong F.M., Hardy R.W. 2000 b. Utilization of fish and animal by-product meals in low-pollution feeds for rainbow trout Oncorhynchus mykiss (Walbaum). Aquaculture Research 31: 585-593.

Sugiura S.H., Gabaudan J., Dong F.M., Hardy R.W. 2000a. Dietary microbial phytase supplementation and the utilization of phosphorus trace minerals and protein by rainbow trout [Oncorhynchus mykiss (Walbaum)] fed soybean mealbased diets. Aquaculture Research 32: 583-592.

Sugiura S.H., Hardy R.W. 2000. Environmentally friendly feeds. Pp. 299-310. In: Stickney R.R. (ed.) Encyclopedia of Aquaculture. John Wiley and Sons, New York.

Tacon A.G.J., Jackson A.J. 1985. Utilisation of conventional and unconventional protein sources in practical fish feeds. Pp. 119-145. In: Cowey C.B., Mackie A.M., Bell J.G. (eds.) Nutrition and feeding in fish. Academic Press, London.

Vielma J., Ruohonen K., Lall S.P. 1999. Supplemental citric acid and particle size of fish bone-meal influence the availability of minerals in rainbow trout Oncorhynchus mykiss (Walbaum). Aquaculture Nutrition 5: 65-71.

Vielma J., Ruohonen K., Peisker M. 2002. Dephytinization of two soy proteins increases phosphorus and protein utilization by rainbow trout, Oncorhynchus mykiss. Aquaculture 204: $145-156$.

Young A., Morris P.C., Huntingford F.A., Sinnott R. 2005. The effects of diet, feeding regime and catch-up growth on flesh quality attributes of large (1+ sea winter) Atlantic salmon, Salmo salar. Aquaculture 248: 59-73.

Received: 2 January 2006 Accepted: 29 May 2006 